\title{
THE RECORDINGS OF JOACHIM, YSAŸE AND SARASATE IN LIGHT OF THEIR RECEPTION BY NINETEENTH-CENTURY BRITISH CRITICS
}

\section{DOROTTYA FABIAN}

School of Music and Music Education

The University of New South Wales

Sydney NSW 2052

Australia

Email: d.fabian@unsw.edu.au
UDC: $78.071 .2 " 18 ": 78.072(410)$

\author{
Original Scientific Paper \\ Izvorni znanstveni rad \\ Received: December 2, 2005 \\ Primljeno: 2. prosinca 2005. \\ Accepted: July 13, 2006 \\ Prihvaćeno: 13. srpnja 2006.
}

\section{Abstract - Résumé}

The press reception of famous $19^{\text {th }}$-century violinists is an important resource for the historical study of performance. Comparing several reports across many years with surviving sound recordings provides some insight into what these recordings might have captured from the artistry of these players. At the same time such a comparison also informs about $19^{\text {th }}$-century expectations, concert practices and taste. Currently held received wisdom regarding the differences between these violinists gains a new perspective, too. For instance, Joachim is upheld as the 'authoritative' interpreter of the classics, especially Bach. But it turns out that, at least for
Bernard Shaw, "Ysaÿe's power of polyphonic playing enables him to challenge any comparison «. Intonation, tone quality and musicianship are all commented on and make the picture more in line with the evidence of the recordings than the black \& white opinion that posits, for instance, a discriminating difference among the violinists in vibrato usage. Recordings are analysed with respect to interpretative style, tempo, vibrato, and violin tone.

Keywords: Joachim; Ysaÿe; Sarasate; Violin Playing; 19th-Century Performance; Sound Recordings; Brahms; J.S. Bach

Among the earliest surviving sound recordings are those made by three seminal violinists of the nineteenth century who were all well-known to the British public: Joseph Joachim (1831-1907), Pablo Sarasate (1844-1908) and Eugène Ysaÿe (1858-1931). In 1903, 1904 and 1912, respectively, they recorded a handful of pieces representing important aspects of their repertoire (re-issued on OPAL CD 9851, see Appendix for full details). Although their interpretation of certain key works 
for which they were famous are not captured on record (for instance concerto movements and Bach fugues in Joachim's case) the selection allows a glimpse into their artistic temperament and violin technique that kept British audiences and critics in rapture for decades. They also provide opportunity to compare historical descriptions with sonic documents and thus to develop a better appreciation of what contemporary listeners experienced and why they reacted the way they did.

Obviously, early recording technology had considerable limitations, but it also ensured that the performances were reproduced unedited which enables a more immediate or live-like impression to be formed (DAY, 2001; PHILIP, 2004; GRONOW and SAUNIO, 1998). To gain a better understanding of what is captured of these violinists' playing style and approach it is instructive to complement the analysis with a study of contemporary public opinion. Such an investigation informs not only what may transpire of their artistry despite the technological constraints but also the nature of sound recordings as evidence of performance practice. Furthermore, comparing reviews with recordings provides insight into nineteenth-century expectations and taste. Contrasting historical opinion with current perception of the performances of these violinists may prove particularly useful in developing an adequate appreciation of available documents whether print or audio (BOTSTEIN, 1992). Finally, a closer study of these recordings offer opportunity for a critical evaluation of currently accepted views regarding the characteristics of Joachim's and Ysaÿe's playing style and temperament. They are probably the most often referred to violinists in studies of modern violin playing and its origins (e.g. MILSOM, 2003; KATZ 1999, 2004) and regarded as important sources for the 'authentic' interpretation of particular composers (e.g. Joachim for Brahms, see MUSGRAVE \& SHERMAN, 2003). A complex re-examination of their technique and musicianship illuminated by the opinion of particular critics who heard them repeatedly over many years is therefore warranted.

The scope of this paper is limited to a study of the contemporary British view, in particular the reviews of Bernard Shaw because such a restriction provides some sense of control in terms of the critics' socio-cultural background and time. After an overview of criticism in the press of the middle of the century, the recordings are analysed in relation to comments from the 1890s bringing the discussion closer to the time of the actual recordings and allowing for more comments on Ysaÿe who was introduced to London audiences only in 1889. This, of course, means that while Shaw reviews Ysaÿe in his prime, he only hears the aging Joachim, a point that must be borne in mind also when listening to the recordings. Actually, the modern listener shares Shaw's experience to the extent that Joachim was 72 at the time of recording (1903) while Ysaÿe's career had just peaked at the age of 54 in 1912.

The three violinists under consideration were born thirteen to fourteen years apart and debuted in London in 1844, 1861 and 1889, respectively. Joachim started out as a child prodigy and his first concert in London, given at the age of 13, was 
an instant success. His reputation and influence in London was cemented by 1858 with several months of residency each year and appearances several times per week in recitals as well as in concertos with the Philharmonic and private musicmaking gatherings (MOSER, 1898; SMART, 1859). The appreciation of his art and contribution to British concert life was famously celebrated in June 1904 to mark the Diamond Jubilee of his first London debut.

Sarasate was less readily accepted by London audiences. His first concert in 1861 was not followed up by another until thirteen years later in 1874 and even then reviews were lukewarm:

A Concerto for the violin by Lalo, was played by Senor Sarasate, neither the composition nor the performer, however, exciting any special sensation. Senor Sarasate has an agreeable, but somewhat thin tone, and executes with neatness (Musical Times, cited in SCHOLES, 1947, p. 347).

From 1879 however, his popularity grew rapidly and he appeared more regularly in London to great appeal.

Although Ysaÿe's debut in May 1889 was more immediately successful than Sarasate's, the critical acclaim he received on the Continent was also slower to be showered on him in Britain's capital city. His virtuosity was never questioned but it took time for London critics to be willing to disregard what they considered a »not always discreetly applied « mastery of technique (SCHOLES, 1947, p. 350).

Mr Ysaÿe is essentially a virtuoso and does not hesitate to appear in that character even when engaged upon a classical work. Some of his tours de force are really astonishing, and worthy of all possible admiration in their proper place. But we may be allowed to doubt whether they should be made in connection with Beethoven's Concerto. ... [when] he appeared a second time, playing... Mendelssohn's Concerto, a Caprice by Paganini, and a Polonaise by Wieniawski [t]he effect he produced was the same as before, and due to the same means (Musical Times, May 1889).

Bernard Shaw was among the first to complain that Ysaÿe did not appear often enough in London (at least not compared to Joachim and Sarasate) and did not receive the appraise he deserved. In the early 1890s he wrote:

[I]f Ysaÿe only perseveres in playing splendidly to us for twenty-five years more or so, it will dawn on us at last that he is one of the greatest living artists... (SHAW, 1981, Vol. 3. p. 968)

Generally speaking, from the reviews it transpires that Joachim was hailed for his taste, artistry, intellectual depth (but Shaw called it "austere«; see SHAW, 1981, Vol. 2, p. 8), distinct articulation, and purity of tone, which was described as powerful and "distinguished by virile energy rather than by voluptuous roundness « (MAITLAND, 1905, p. 24). Towards the end of the period some dissenting 
opinions were also voiced. When The Strad commented on Joachim's performance of the Beethoven Concerto in the August 1900 issue it still acknowledged the violinist's "great dignity and depth of style, vigour without bluster, and clear technique«, but also noted that the performance was »tempered by the most artistic reticence" and that »the latter virtue [was] carried to such excess as to actually become a fault. « The reviewer wished for »a little more detailed expressiveness in Joachim's solo playing « (cited in ROTH, 1990, p. 368). Sarasate was acknowledged for his technique and "neat execution" but his "agreeable tone" was regarded "somewhat thin " (Musical Times, 1874) or "wiry" (SHAW, 1981, Vol. 1, p. 659). Ysaÿe was similarly judged to be »essentially a virtuoso « whose »admirable« abilities created enormous success in pieces by Saint Saëns or Wieniawski but were out of place in Beethoven's and Mendelssohn's concertos. The critic of the Musical Times consented in 1889 »to overlook whatever was not in the severest taste, out of regard for the artist's really remarkable skill« (cited in SCHOLES, 1947, p. 350). By the early 1900s reviewers started to appreciate his musicianship more. On the occasion of him performing Beethoven's Concerto a reviewer wrote the following: »his tone was more lush than ever, his intonation as accurate, his bow as graceful and individual, and his intelligence as acute, so that the performance was again a memorable one« (The Strad, June 1902, italics added).

Looking at the reviews in more details the earlier period turns out to be less informative. As José Antonio Bowen notes in his doctoral dissertation, accounts of concerts in the British press around the mid-nineteenth century tend to focus on the program, that is, on the works performed, rather than their performances (BOWEN, 1993, p. 480-500). Of Joachim's historic first concert in London, when he performed Beethoven's Violin Concerto conducted by Mendelssohn the daily press's reports made only a cursory mention of the »wonder boy « highlighting the fact that he played all three movements from memory and that he composed the candenzas himself. Otherwise the reviews focused on the merits of Beethoven's work and, especially, the new composition: Mendelssohn's incidental music to a Midsummer Night's Dream. Chorley, for instance, writes thus for the Athenœum (1 June, 1844):

Then came Beethoven's Violin Concerto, played by Herr Joachim...., and, what more, played with. It was given, too, by memory, with a thorough understanding of the author, and command of his instrument. Nothing could be firmer, more sensible, or more sensitive, than the reading of the composition; yet this, when read is anything rather than gracious to execute; while to prove past doubt that it is not a mere bookknowledge of music which he possesses, Herr Joachim introduced a pair of cadences into the blank spaces left according to old concerto fashion, which will be long talked of, as marvels of musician-like skill and young invention. We have now to speak of Dr. Mendelssohn's music to the Midsummer Night's Dream... (cited in BOWEN, 1993, p. 489). 
In the Spectator (1 June, 1844) we read that

The Concerto for the evening stood justly alone. The boy Joachim from thirteen to fourteen years old, has obtained on his instrument the firmness, certainty, and command, and above all the style of an artist of five and thirty...Joachim is not only an experienced concerto-player-he played the whole of Beethoven's Concerto from memory, with the utmost self-possession-but a composer. The Paganinian cadences he produced were of a first-rate description, and are said to be his own; which some will hardly go the length of believing (cited in BOWEN, 1993, p. 489).

Davison, who was one of the most important critics of the time, wrote two reports of the concert, one in The Musical World, the other in The Times. In the former while acknowledging Joachim's "astonishing « performance he primarily critiqued Beethoven's concerto and praised Joachim's cadenzas. In The Times (28 May, 1844), however, he also provided a rare glimpse into the particulars of the execution:

Joachim ... by his clear and distinct articulation, his perfect intonation, and a conception of his subject which denotes almost a mind kindred with that of the composer, has produced a perfect whole, and so blended the solo instrument with the rest of the composition as to present this great masterpiece with the effect which the author intended (cited in BOWEN, 1993, p. 490).

Another review which is more specific about the techniques used and provides information on performance practice appeared in the Morning Chronicle (28 May, 1844):

[Joachim] has every quality of a great performer; a full rich, vocal tone; a rapidity of bow and finger which no difficulties can embarrass; great force and vigour, united to the utmost delicacy of taste; and much feeling and expression. He does not belong to the Paganini school, and executes the utmost difficulties in the highest regions of the scale, without even having recourse (or at least very rarely) to the use of harmonics (cited in BOWEN, 1993, p. 492).

The Illustrated London News (1 June, 1844, cited in BOWEN, 1993, p. 491) also comments on Joachim's tone »of the purest cantabile character « and his »most marvellous execution «. His style is deemed to be »chaste, but deeply impassioned at moments «. Importantly, just like Davison's review in The Times quoted above, this critic also alludes to an approval of Joachim's interpretation on the basis of it being true to the composer's intentions or »spirit « when he claims that Joachim's performance »was an eloquent vindication of the master-spirit who imagined it«.

As José Bown points out (ibid.) these Victorian critics are disinclined to appraise performances. Instead they search for objective information to relay to their readers. Throughout the first half of the century, composition was thought to be 
the more objective component of music and critics seem averse to assess performances even when the opportunity presents itself. According to Bowen such an occasion arose in 1852, for instance, when Joachim played the Mendelssohn Violin Concerto at the Philharmonic just three days after Sivori, another violinist renowned for his excellence had performed the same concerto with Berlioz and the New Philharmonic. The Illustrated London News critic published the two reviews separately and made no cross-reference, praising each for their individual merits. He found Sivori's playing »most finished and graceful«, his interpretation »elegant« and confirmed that the violinist combined »the purity of tone of the Italian, the sentiment of the German, and the brilliancy of the French schools of violin playing «. In Joachim's playing he welcomed the "grand and intellectual style « and praised the "purity of tone and perfection of passage playing«. He also noted that the »allegro finale rattled off at the most prodigious pace ever yet taken by any violinist«. While acknowledging that »this was Mendelssohn's own reading of the movement « he objected that it may be doubted whether distinctness was not in some degree sacrificed «(BOWEN, 1993, pp. 495-98).

The few reviews that did compare the two violinists provide valuable insight into contemporary priorities and preferences. Grüneison in the Morning Chronicle observed that

... in almost every respect Joachim's idea and executive tendencies differed from those of Sivori. The reading and the rendering of each were masterly, but taken from different points of view, and evidently inspired by different instincts of art (Morning Chronicle, 1 June, 1852).

He found "Sivori's execution more perfectly neat, his brilliant staccato manipulation more adroitly and crisply furnished, and perhaps his tone ... sweeter, particularly in the very high notes...«. At the same time he claimed that

Herr Joachim has the advantage in breadth and sweep, and meaning of style. He gives the composition with more energy and more sentiment than his rival, and thus produces more quiet sensation in his slow and cantabile passages, while Sivori's great triumph is the finale, which is from beginning to end one blaze of executive brilliancy, and one tangle of executive difficulty (Morning Chronicle, 1 June, 1852).

The Spectator's reviewer was slightly more critical. He found them both »excellent« but claimed that

Joachim showed more physical power; his tone is of surpassing volume; his accent and emphasis are stronger than Sivori's, and in passages of great force and energy he has the advantage. But in exquisite purity and vocal quality of tone, and in the Italian grace and roundness of his cantabile phrases, we would be inclined to give the palm to Sivori (The Spectator, 5 June, 1852). 
Davison also made a tentative comparison in his review of Joachim's concert which followed a separate praising account of Sivori's performance. It seems that he, too, slightly favoured Joachim's for it was a "grander, a more finished, and altogether a more artistic performance we have ever listened to«. Contrary to Grüneison in the Morning Chronicle he noted the »extreme rapidity with which [Joachim, rather than Sivori] played the last movement « of the Concerto and added, just like the other critic, that this tempo choice is »in consonance with Mendelssohn's own views «. Perhaps the fast speed of Joachim's rendering was nevertheless more acceptable for he added that $»$ the neatness and decision of the execution were never once endangered; no mechanism could be more faultless; while fire and expression gave life and vigorous character to the whole « (cited in BOWEN, 1993, p. 498).

By the end of the century, and especially with Bernard Shaw's writing, the focus on composition had gradually weakened. As repertoire started to be standardized comparison became more common, especially in the popular concerto genre. Concertos were much more frequently performed than any other types of composition for violin; even at so-called recitals violinists would often play a concerto with piano accompaniment. Among the violin concertos Beethoven's and Mendelssohn's were the most popular, as we have already seen. Even Sarasate, who was not famed for playing classical works, performed the latter in April 1883. According to the Musical Times »the anxiety to listen to his interpretation of this popular work was so great that the room was crowded «. The reviewer compared his »emotional style« to »Herr Joachim's highly refined and intellectual interpretation, « but admitted that »two distinct readings may be given of a great work «, and criticised Sarasate only for »the excessive speed with which he played the last movement« (SCHOLES, 1947, p. 348).

There are at least two noteworthy aspects of these reviews for the current examination: Firstly that Joachim is praised from the start for abiding by the composers' intentions, for his intellect, artistic taste and depth of interpretation. These observations recur throughout except in Shaw who expresses somewhat different views, as will be shown. The emphasis on appraising a performance for its respect for the composer's intention documented from at least 1844 onward should be a sobering revelation for anybody claiming this attitude to be a modernist mid-twentieth-century preoccupation. Secondly, there is a strong sense of discomfort regarding the fast execution of the third movement within the context of Mendelssohn's well-known preference for fast tempi. This is significant for the evaluation of Ysaÿe's surviving recording of this piece which is also rather fast and facile. As Ysaÿe was often criticised for being a mere virtuoso who habitually diverted from the written score (see some citations below or ZEITLIN, 1990), this recording could be regarded as a supporting document for such a claim. However, in light of the mentioned reviews it seems more appropriate to appraise it rather as an example of the then current style, even though his interpretation is the only one that has been preserved on record from that period. As was shown, most 
performances of this $3^{\text {rd }}$ movement were criticised for their »extremely rapid « tempi, although there was some disagreement whether any of them actually »sacrificed distinctness « or »neatness of execution « (see quotes above). It has to be further noted that Joachim's basic approach of the entire concerto was compared to Sivori's (1852 cited in BOWEN, ibid.) and Sarasate's (Musical Times, April 1883) as being »a more artistic performance «; as having more »breadth, energy, sweep, and meaning of style «, showing more physical power and volume, and providing more sentiment and stronger accents and emphases. In other words, Ysaÿe's reading might be closer to Sivori's and/or Sarasate's than Joachim's regardless of the fast speed for which all were criticized, except that Shaw once opined that at a concert in 1891 "Ysaÿe played Mendelssohn's concerto magnificently: Sarasate and Joachim rolled into one could not have done more (SHAW, 1981, vol. 2, p. 477).

To put Ysaÿe's tempo in a modern context I randomly selected three further recordings made at various points of the twentieth century of the same Allegro molto vivace section of this movement. ${ }^{1} \quad$ A quick comparison of duration indicates that Ysaÿe's tempo is indeed considerably faster than the others, lasting only 4'52". In contrast, the period instrument version by Monica Huggett from 1992 lasts $6^{\prime} 01^{\prime \prime}$. The two from the middle of the twentieth century have a basically identical overall tempo: the duration of Szigeti's recording in 1933 is 5'42", while Grumiaux's from 1960 is $5^{\prime} 43^{\prime \prime}$. Typically a tempo difference of $6 \%$ or greater is noticeable even by inexperienced listeners (e.g. SHELDON and GREGORY, 1997; KUHN and BOOTH, 1988). In Ysaÿe's recording four bars (805-808) are skipped (the last beat of bar 804 is adjusted to be similar to the last beat of bar 808 but an octave lower). Thus the tempo, calculated on the basis of duration and number of beats, is crotchet $=164$ in Szigeti's recording and crotchet $=189$ in Ysaÿe's.

Ysaÿe's recording sounds a little sharp at times compared to the other two recordings on modern violin. However, it would seem hasty to attribute his extremely fast tempo to possible recording or playback inaccuracies on the basis of this slightly sharp pitch. Compared to the accompanying piano, Ysaÿe's intonation is accurate. On the other hand pitching may fluctuate according to the use of vibrato, as in Szigeti's recording (see Fig. 1). He starts the first long note flat and then pulls it up while the volume increases and the vibrato intensifies and widens. Measured on the fourth harmonic (the fundamental being the first) for reasons of clearer reading, the width of Szigeti's vibrato grows from 120 Herz at the beginning of the long high B (bar 6) to 210 by the end while the pitch itself goes up by about 30 Herz. This is measured at the fundamental level: starting at 961 and finishing at 991 (the correct frequency of B5 on a standard modern keyboard is 987.77 Herz, see Joe WOLFE, 2001). In comparison, Ysaÿe's B5 starts and finishes around 987 Herz (982-1008 embrace the edges of alternative readings). The width of his

${ }^{1}$ Szigeti on NAXOS Historical 8.110948; Grumiaux on Philips Duo 442287-2; Huggett on EMI Classics for Pleasure 5748782 
vibrato is fairly even and narrow, ca. 123 Herz difference was measured at the third harmonic. Bowing and other performance features, including phrasing and passage work all sound natural enough to discount the possibility of incorrect recording or playback tempo. Rather, one may conclude that this version provides an example of what nineteenth-century critics regarded as an »extremely rapid « tempo. That this execution sounds incredibly fast to modern listeners as well implies that in certain things taste and musical judgments have not changed much over the past 150 years - an important lesson to keep in mind when debating the use and meaning of historical sources and descriptions.
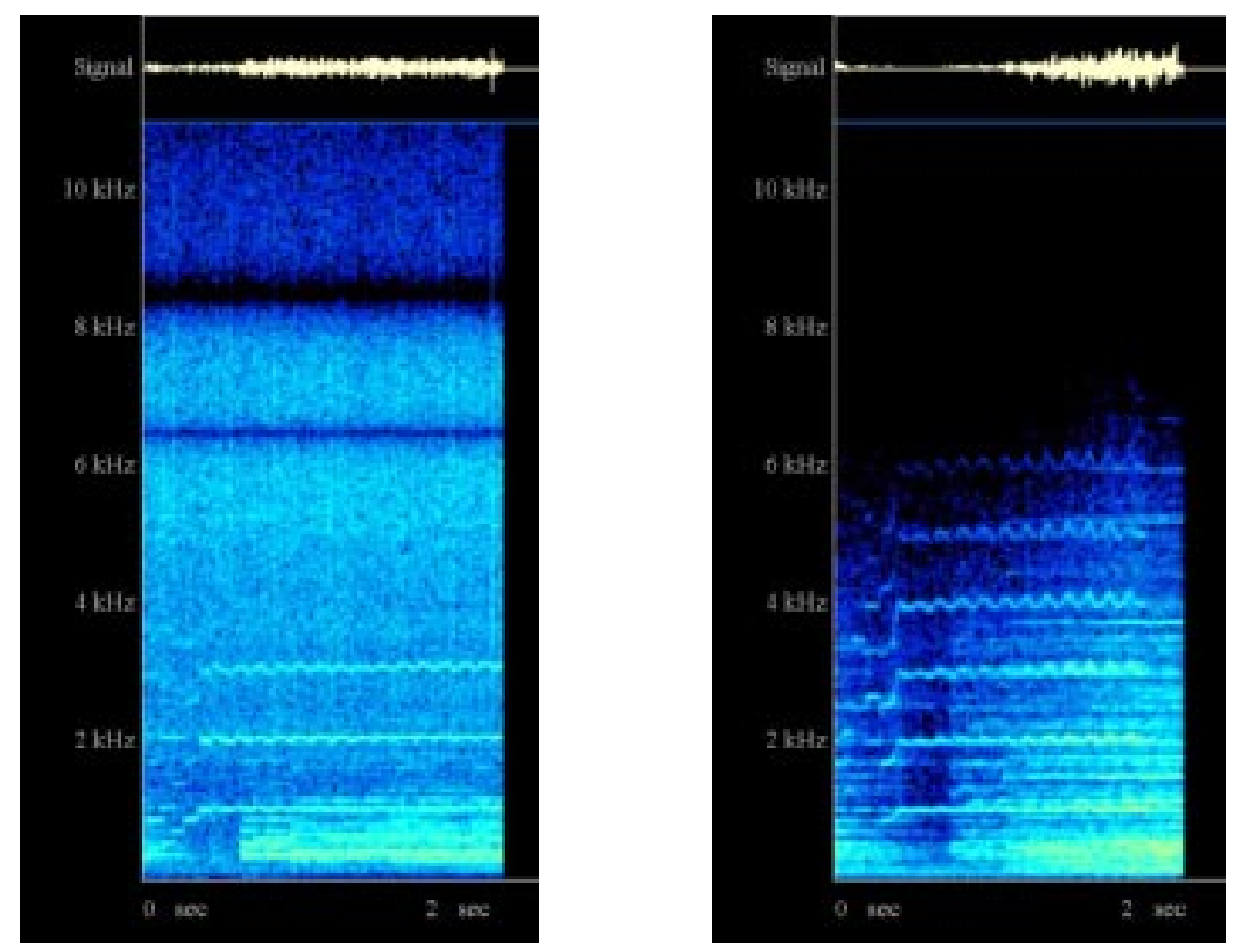

Figure 1: Two spectrograms that were used to measure frequencies: Ysaÿe playing B5 $\left(=\mathrm{B}^{2}\right)$ in bars 6-7, Szigeti playing B5 $\left(=B^{2}\right)$ in bars 6-7 of Mendelssohn's Violin Concerto in E minor, $3^{\text {rd }}$ movement, Allegro molto vivace section. A spectrogram visualizes what the ear hears: sounds (vertical axis) passing through time (horizontal axis). Volume, tone production and recording technology influence the intensity of colour and the number of visible and measurable partials. Vibrato makes the sound waves look wavy rather than straight. Note the slightly upward angle of lines (partials) of Szigeti's spectrogram which indicate that the pitch is shifting upward. 
Turning the attention to the later period one finds more comparative comments regarding performance styles. Importantly, Bernard Shaw often disagrees with the much repeated views of others, especially in Joachim's case, but one has to keep in mind that he never heard the child prodigy violinists but only the aging artist. He criticised Joachim's intonation and questioned his »high-class « taste on several occasions, for instance when he played Bruch's concerto. In 1891 Shaw summarized his opinion of the three violinists thus:

Sarasate never insists on his extraordinary feats: he treats his own skill as a matter of course... Joachim, whose cadenzas... are much better than Ysaÿe's, takes his place beside the conductor and his orchestral colleagues as the interpreter of Beethoven, whose supremacy he never obscures for a moment. ... Ysaÿe is Titanically emphasizing himself. ... At present he is more interesting as a prodigy than delightful as an artist (Vol. 2, p. 329).

Later the same year Shaw compared Sarasate to Ysaÿe. He noted the thinness of Sarasate's tone and claimed that Sarasate appeared »to be perfectly indifferent whether he [was] playing Mackenzie or Beethoven «. At the same time he acknowledged that the comparison also highlighted Sarasate's »extraordinary smoothness and certainty of execution, and [the] fine quietude with which he performs miraculous technical feats « (SHAW, 1981, Vol. 2, p. 365).

There are several examples among the recorded performances that illustrate the contemporary opinion of Sarasate's art fairly well. His thin tone, secure intonation and self-effacing virtuosity are particularly well preserved in his interpretation of Chopin's Nocturne in E flat, Op. 9 No. 2 and in the middle section of his own Zapateado. Although thin, the tone is clear and precise even in the highest ranges and the fastest scales and figures. The final cadenza at the end of the Nocturne is beautifully but lightly shaped and ornamental rather than a show of virtuosic display. In his own compositions the variety of technical feasts are conspicuous but he delivers them with such ease and nonchalance that they seem entirely natural and integrated into the compositional fabric. Taken together with the other recorded performances, especially that of Bach's E major Preludio- - the fastest version ever recorded (FABIAN, 2005, p. 98) -and his other compositions, one can also sense why he was criticised for playing everything with the same casual or indifferent attitude. This, however, does not mean that his playing was unmusical or dry. In a comparison with Ysaÿe Shaw actually gives the palm to Sarasate with regards to phrasing:

Ysaÿe disappointed me [in Mendelssohn's Concerto]. ... In the cadenza he played every phrase so as to make a point... the audience... did not recognise that the phrase was an integral part of the movement - a fragment of the opening phrase. Now, when Sarasate played the same cadenza on Saturday, everybody recognized the reference, and nobody had the feat of execution obtruded on them (The Star, 24 May 1889, cited from SHAW, 1981, Vol. 1 pp. 638-9). 
Although Shaw generally favoured Ysaÿe for his »superb, prodigious, transcendent impetus «, »strong and steady « tone and phenomenal dexterity, he also criticised him for playing too fast and for "always missing the spirit of the composition, and insisting on the wonders of the fiddling " (The Star, 1889). On the occasion of Ysaÿe performing Vieuxtemps's Fourth Concerto in 1890 he wrote the following:

Of course he overdid it. Instead of being content with a speed which would have been impossible to any other violinist, he dashed into a speed impossible to himself; but what he succeeded in doing without sacrificing the accuracy of his intonation or the quality of his tone, was astonishing. And he knew it, and revelled in it. As I said the other day, Ysaÿe is bumptious. But then he has a good deal to bounce about, and must have paid a heavy price in labour for his dexterity (The Star, 5 April 1890, cited from SHAW, 1981, Vol. 2, p. 17).

Eventually Shaw wrote rave reviews of Ysaÿe's concerts, claiming him to be »the greatest fiddler in the world « (Shaw, 1891, Vol. 2, p. 95). He came to regard Ysaÿe "Sarasate's only serious rival among players of his generation « and asserted that his »individual force is of European volume« (Shaw, 1981, Vol. 2, p. 302-4). He praised Ysaÿe's »terrific technique« and »combination of a Latin finesse of execution with a German solidity of tone « and regarded Ysaÿe's »fondness for the intensely French Saint-Saëns, his self-assertiveness, his readiness to sacrifice higher artistic qualities to the speed of a dazzlingly impossible presto « as features of »his distinctively Belgian « character (SHAW, 1981, Vol. 2, pp. 302-3).

Perhaps the most striking among Shaw's judgments are the sentences that betray his preference for Ysaÿe's Bach-playing over that of Joachim, who was, and has been, universally acknowledged as the Bach-violinist of the nineteenth century. In 1890 he reported in The Star that Ysaÿe had showed Londoners »what real Bach-playing meant « with his performance of the E Major Preludio and Gavotte (SHAW, 1981, Vol. 2, p. 17); and in 1891 he wrote in The World that:

[Ysaÿe's] selection of the Bach fugue may have been partly prompted by our habit of saying that nobody can play Bach but Joachim. ... Ysaÿe's power of polyphonic playing enables him to challenge any comparison on this score as far as technical mastery goes (SHAW, 1981, Vol. 2, p. 304).

Of Joachim, he often wrote negatively, critiquing him primarily for a faulty intonation. One of his amusing reviews was published in The Star in 1890:

I must first mention, however, that Joachim was never to me an Orpheus. Like all the pupils of Mendelssohn he has seldom done anything with an allegro except try to make speed do duty for meaning. Now that he is on the verge of sixty he keeps up the speed at the cost of quality of tone and accuracy of pitch; and the results are sometimes, to say the least, incongruous. For instance, he played Bach's sonata in C at the Bach choir 
Concert at St James's Hall on Tuesday. The second movement of that work is a fugue some three or four hundred bars long. Of course you cannot really play a fugue in three continuous parts on the violin; but by dint of double stopping and dodging from one part to another, you can evoke a hideous ghost of a fugue that will pass current if guaranteed by Bach and Joachim. That was what happened on Tuesday. Joachim scraped away frantically, making a sound after which an attempt to grate a nutmeg effectively on a boot sole would have been as the strain of an Eolian harp. The notes which were musical enough to have any discernible pitch at all were mostly out of tune. It was horrible - damnable! Had he been an unknown player, introducing an unknown composer, he would not have escaped with his life (SHAW, 1981, Vol.1, pp. 933-4).

Unfortunately Ysaÿe did not record any Bach, as far as I could ascertain, nor are there any surviving recordings of Joachim's performance of a Bach fugue. So an immediate comparison is not available. Nevertheless, Shaw's above review gives us a glimpse into what he did not favour in the latter's performance, and by implication what Ysaÿe's playing might have been like. On the other hand two Bach movements are available in Joachim's performance from 1903 which provide data for some further speculation. His rendering of the $\mathrm{G}$ minor Adagio (BWV 1001) and the B minor Bourrée (BWV 1002) does not seem to justify the severity of Shaw's judgment, at least not to me. The intonation and tone quality are faire, certainly not »horrible or damnable«. That Shaw's judgment of Joachim's intonation was regarded contentious even by contemporaries is testified to by Maitland who defended Joachim against the charges »of some particularly inapt journalist « when he stated: »True, in recent years the top joint of the little finger of the left hand has become weakened, and it occasionally fails to obey the brain's demand " but then argued that Joachim used just intonation rather than tempered tuning (MAITLAND, 1905, pp. 32-3). At the same time one can sense what made Shaw prefer Ysaÿe's polyphonic playing when one hears the rather harsh and 'whipping' bowing of four-part chords and the penetrating tone of Joachim's violin. On the positive side is Joachim's inflected, rhythmically flexible overall style which creates easy-to-follow textures and musical phrases. All in all I feel that Joachim's gesture-full interpretative style is better captured by Sir Francis Tovey who described it in the Musical Gazette (1899) as »elastic«.

The moulding of [Joachim's] phrasing... is inimitable, for it consists of slight modifications of the strict metronomic values of the notes, together with slight variations of power such as no marks of expression could convey. 'Elasticity' is the word which best expresses the effect of his delivery. ... as in a perfect rubato there is a feeling of resilience, of rebound ... constant restoration of balance between pressure and resistance... It is, perhaps, this subjection to the real laws of rhythm that makes Joachim an extraordinarily easy player to accompany; one seems to know what he is going to do before he does it, and the notes of his phrases seem to follow a natural curve which, once started, must pursue an inevitable course (cited in MAITLAND, 1905, p. 28). 
If not in Bach, Ysaÿe's and Joachim's art may be meaningfully compared in nineteenth-century repertoire. Interestingly the use of vibrato is fairly similar in Ysaÿe's interpretation of Fauré's Berceuse and Joachim's rendering of his own Romance (Fig. 2). Although at the fundamental pitch level (first partial) the image of Joachim's performance seems straighter, at the higher partials the wavy lines betray the use of vibrato. Moreover, the width of their respective vibrato is also fairly similar; at times narrower (especially at beginning of notes), at times slightly wider but fairly evenly regulated.

a)

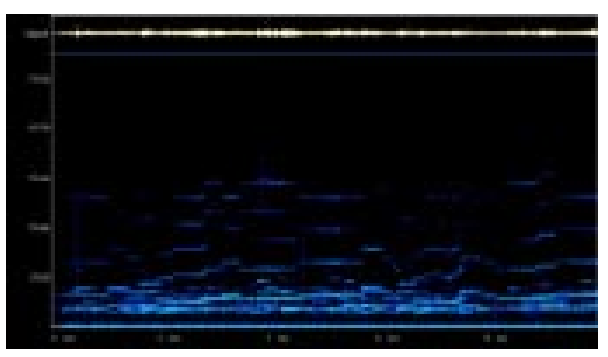

b)

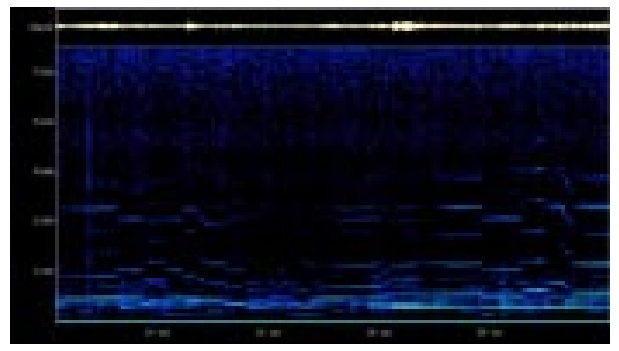

Figure 2: Spectrogram images from (a) Joachim's recording of his Romance and (b) Ysaÿe's recording of Fauré's Berceuse.

Ysaÿe's tone is nevertheless warmer and somewhat richer than Joachim's. This is in line with the view reiterated from the beginning of the twentieth century that deemed Joachim's tone »dry «by comparison with Ysaÿe's »lush« timbre (The Strad, August 1900). However, recording quality needs to be especially borne in mind when discussing tone; the number of partials recorded could be due to either tone production or better equipment. The difference in timbre can be heard even more in their respective versions of Brahms' Hungarian Dances where Ysaÿe's vibrato is more audible and constant than Joachim's (Fig. 3). The visual illustrations show that certain longer notes are played without obvious vibrato by Joachim (see 'straighter' lines at beginning of excerpt, between portamento curves at around 20 sec. and also at $22 \mathrm{sec}$.) and that Ysaÿe's vibrato is occasionally quite wide (compare width at 2 and $4 \mathrm{sec}$. with note at $6 \mathrm{sec}$. or at end of excerpt). These readings corroborate Katz's aural analysis of Joachim's recordings of the Brahms pieces (KATZ, 1999, 2004). 
a)

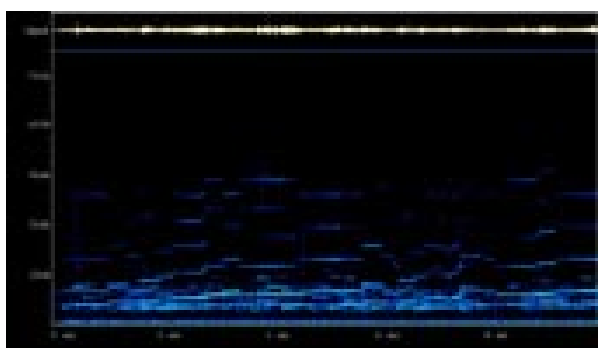

b)

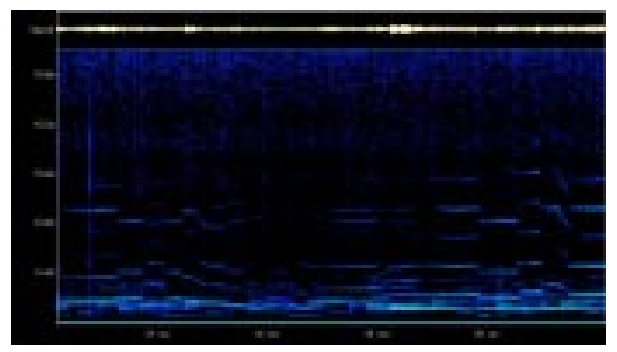

Figure 3: Spectrogram images from (a) Joachim's recording of Brahms' Hungarian Dance No. 1 and (b) Ysaÿe's recording of Brahms' Hungarian Dance No. 5.

A great deal has been written about the origins and development of the 'conspicuous' violin vibrato that is typically heard on sound recordings from ca. the 1930s onward (e.g. FABIAN 2005; HAUCK, 1975; KATZ, 2000; MILSOM, 2003; PHILIP 1992, 2004; TURNER, 2004). Roth's verdict is the closest to the observations reported here. He claimed that although "Sarasate, Joachim and others of that era used varying degrees of vibrato, but compared to the great tonalists who followed, their vibratos and its usage were pallid. « In contrast »Ysaÿe possessed a well developed vibrato in the 'new' manner, though he would often play an entire passage without vibrato effect«(ROTH, 1990, p. 369). What transpires is not so much the use or lack of vibrato, but its different role in the overall apparatus of the violinist. As Katz noted (1999, p. 122): »Vibrato did not define Joachim's sound; it was a means to various ends, whether to distinguish repeated pitches or to intensify the high point of a melody«. Overall, it seems that Joachim and Sarasate simply project the sound less than later violinists and use vibrato primarily for louder passages. Attention should also be drawn to the importance of considering repertoire when discussing vibrato. For instance, Joachim does not seem to rely on the device in the Bach pieces as much as he does in his Romance and the Hungarian Dances. As both Ysaÿe and Sarasate recorded only romantic compositions (save the fast Bach Preludio in E major by Sarasate) these clarifications have limited scope for generalisation due to a lack of comparable evidence. They are nevertheless in line with Milsom's (2003, p. 118) view who regards it a mistake to "assume that the device was scarcely used $«$.

In terms of contemporary opinion, it seems that critics managed to find the right words and metaphors to describe the tonal qualities of these violinists - at least to the extent as it can be judged by listening to the surviving recordings. Sarasate's tone does indeed sound »sweet and thin «, Joachim's more steely (»wiry«) and penetrating (»virile«), while Ysaÿe's is the mellowest and richest (»voluptuously luscious «). 


\begin{tabular}{|c|c|c|}
\hline Artist & Received opinion (critics) & Evidence of recordings \\
\hline \multirow{4}{*}{$\begin{array}{l}\text { Joachim } \\
\text { 1831-1907 } \\
\text { Rec: } 1903\end{array}$} & Clear and virile tone & Penetrating, steely tone \\
\hline & True to composer & Gesture-full performances, \\
\hline & Depth of musicianship & $\begin{array}{l}\text { often quite liberal tempo } \\
\text { \& rhythm }\end{array}$ \\
\hline & No (limited) use of vibrato & $\begin{array}{l}\text { Less vibrato in Bach, quite } \\
\text { 'normal' in Romantic music } \\
\text { but sound is softer, i.e. less } \\
\text { projected }\end{array}$ \\
\hline
\end{tabular}

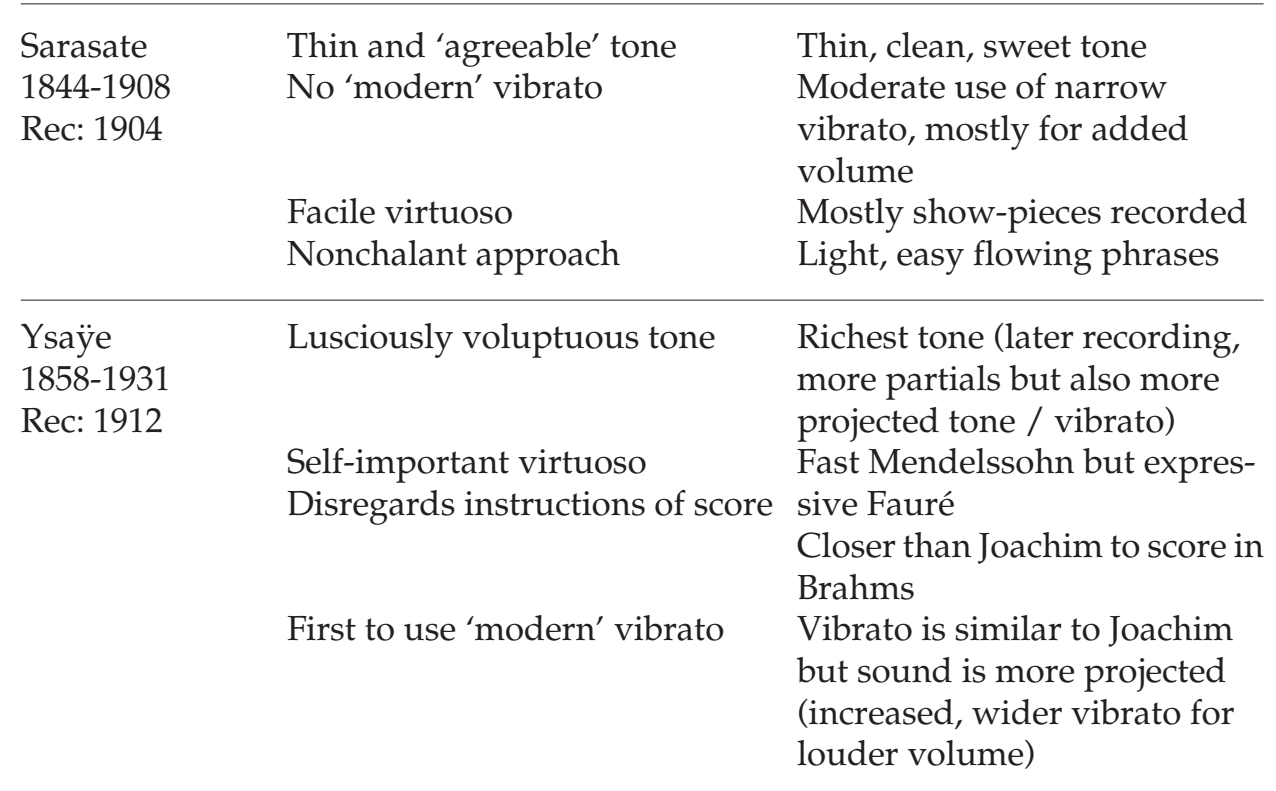

Table 1: Summary of Joachim's, Sarasate's and Ysaÿe's artistic characteristics as collected from public documents and as observed through the analysis of surviving sound recordings.

Finally, a brief comment on their respective artistic temperament as evidenced in these recordings is due (see Table 1 for summary). Given the diversity of the repertoire and the lack of recordings by all of them of the same piece or of those most often mentioned by reviewers (e.g. Beethoven's and Mendelssohn's Concertos) this task is difficult and the conclusions conjectural. The choice of pieces recorded by Sarasate nevertheless supports the view that he was a facile virtuoso who seems not to care whether "he is playing Beethoven or Mackenzie«. Shaw's 1889 statement sums up perfectly the impression a listener gains from hearing his recordings: 
[Sarasate] never interprets anything: he plays it beautifully, and that is all. He is always alert, swift, clear, refined, certain, scrupulously attentive and quite unaffected (SHAW, 1981, Vol. 1, p. 644).

Joachim and Ysaÿe are a bit easier to compare because they both recorded a Brahms Hungarian Dance, even though not the same number. Bowing and phrasing are similarly smooth and sensitive with fairly equal and liberal use of portamento in the slower sections. Yet Joachim's Brahms sounds freer with stronger gestures and tempo fluctuation as well as greater flexibility of rhythm while Ysaÿe's Brahms sounds more robust and virtuosic, its tempo and rhythm more controlled. In some respect, then, the 'liberal' Ysaÿe and the 'faithful to the score' Joachim exchange their respective reputations in these works.

Tempo measurements and beat tracking confirm these impressions (Figs. 4-8). Tapping the beat to Joachim's rendering of Hungarian Dance No. 2 is rather challenging as hardly any two bars have the same pulse (mostly just those pairs of bars with a dotted crotchet-quaver and two crotchets as in b. 3-4, 7-8 etc.). He slows right down for the poco rit. and poco sostenuto sections (e.g. bars 9-16 or 25-27) and accelerates steadily during the crescendo of the Vivo section (b. 49-84) until the climactic forte is reached in bar 69. Here he provides strong accents on the down-beat chords causing slight delays and observes the leggiero marking for the semiquavers (b. 73-6). Dynamics, tone colour and intonation change throughout to suite the particular moment's expressive content. Being Hungarian and having heard countless urban and traditional gypsy musicians in a variety of settings I think I am allowed to say that Joachim's 'style hongrois' is as authentic as it can be. The elasticity of tempo, rhythm and tone colour would already guarantee this, but the means that make Joachim's interpretation truly genuine gypsy-style is intonation, the way he modulates pitches to create the bitter-sweet effect called upon by Brahms in bars like 12-16 and their equivalents (for more on Brahms' style hongrois see BELMANN, 2003).

In comparison Ysaÿe's performance of Hungarian Dance No. 5 seems calculated. This is not to say, of course, that he plays metronomically. There are agogic accents, overdotting and general rhythmic flexibility, but in his interpretation tempo fluctuations sound regulated because they are predictable and measurable. For instance he always plays the semiquaver passages (e.g. bars 13-15, 29-31) faster and the repetition of phrases has the same strategy and degree of liberty (Figs. 6-7).

The Vivace middle section shows even more clearly Ysaÿe's strategic approach. The first 6 bar ( 24 beats, including repeat) are steady and fast. In the next section he systematically differentiates between the poco rit and the in tempo pairs of bars taking the former about three times slower but always returning to the main tempo for the latter (Figure 8). 


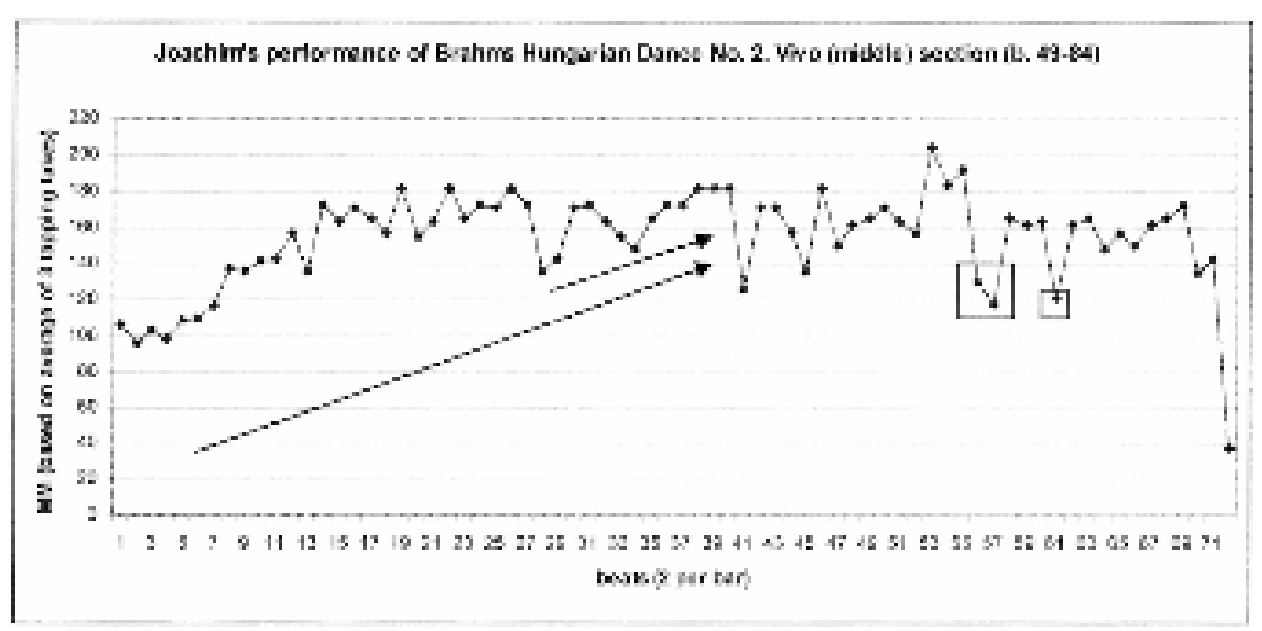

Figure 4: Beat-level tempo map for the middle section (Vivo, bars 49-84) of Joachim's performance of Brahms' Hungarian Dance No. 2. Note the acceleration until bar 69 (beat \#42), with a pull-back at the $p$ tenuto and leggiero in bar 63 (here \#28), and the slight pause caused by the agogic accent on the downbeat of these bars (cf. drop in tempo/beat length at these points and simile, e.g. $f$ in b.77 [beat \#57-8]). Note also the drop in tempo at the end of the section. This occurs because he extends the last quaver of the section (marked by a pause sign) by about a dotted crotchet.

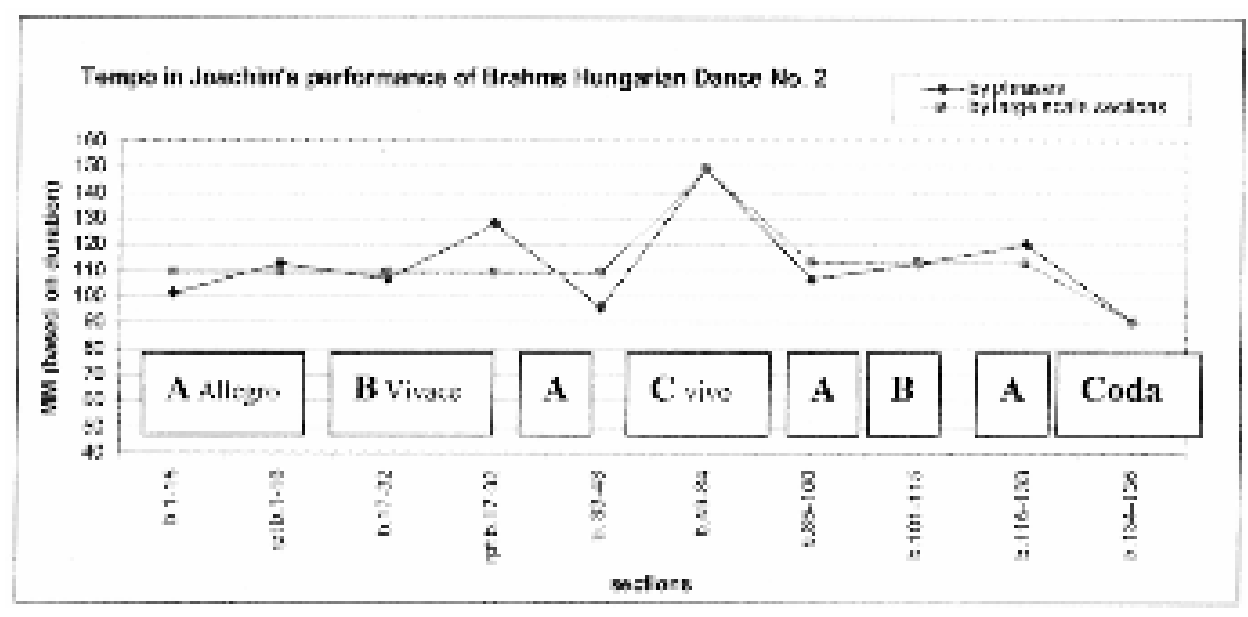

Figure 5: Overall tempi in Joachim's performance of Brahms' Hungarian Dance No. 2 calculated from durations. The middle section (Vivo, bars. 49-84) is faster than the A section (bars 1-48), but the vivace part B (bars 17-32) of the A section has a rather ambivalent tempo relationship to the opening Allegro non assai phrase (bars 1-16 \& 33-48) because Joachim plays only bars 3-4 and 7-8 (and equivalents) in measurable tempo giusto. The rest is entirely elastic tempo rubato. Nevertheless Joachim has a very secure sense of tempo, as those tempo giusto bars always have the same MM value: crotchet $=117$. 


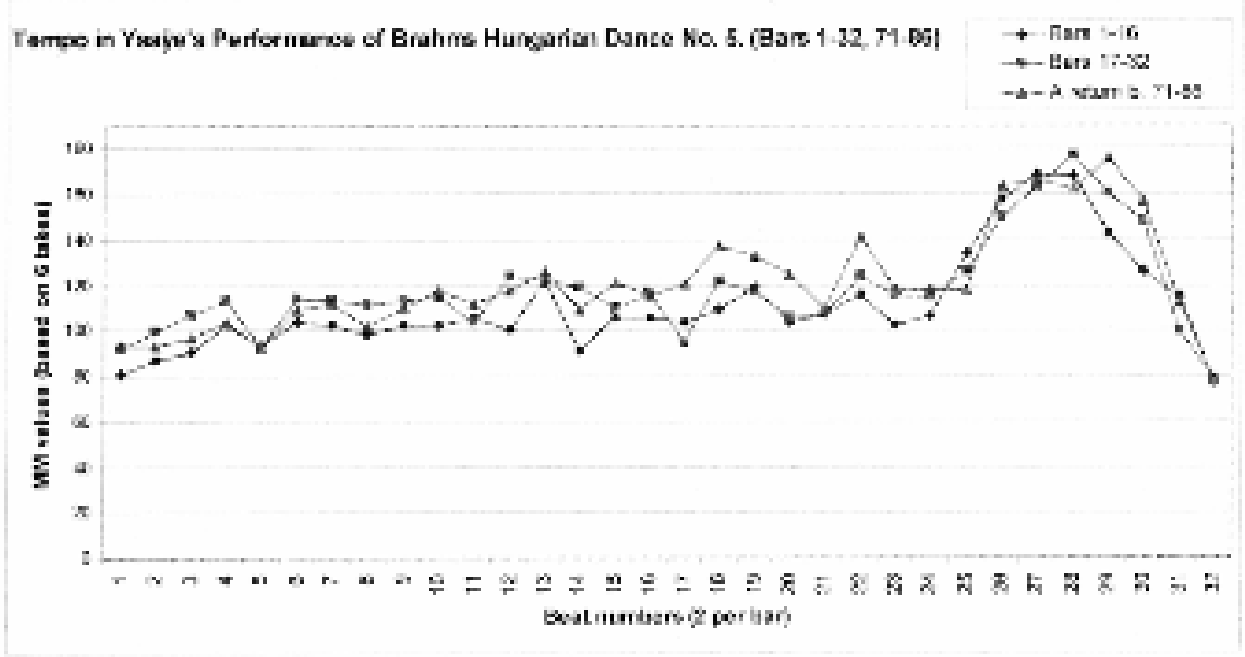

Figure 6: Tempo in bars 1-16 with repeat (b. 17-32) and the material's return at bar 71 in Ysaÿe's performance of Brahms' Hungarian Dance No. 5. MM values were calculated with the tapping method (average of 6 takes). The tempo map shows the faster tempo of bars with semiquavers (b. 13-15, 29-31 i.e. beat nos. 26-30) and Ysaÿe's secure sense of tempo and deliberate strategy because the return of the A section maps easily onto the original statement of the material.

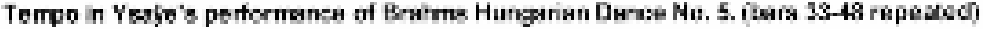

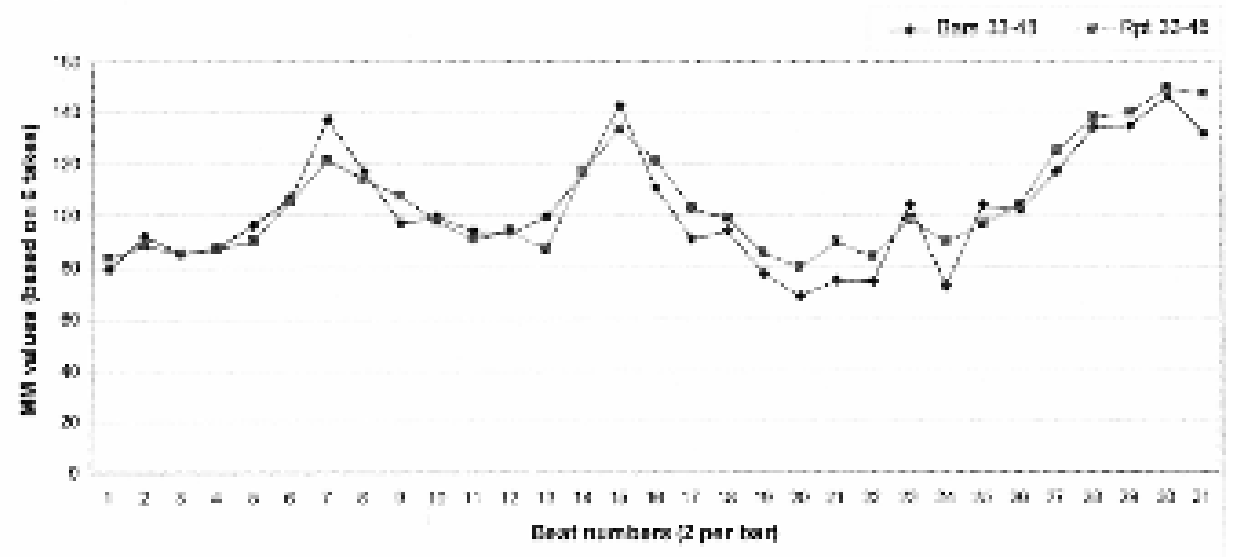

Figure 7: Tempo in second half of the A section in Ysaÿe's performance of Brahms' Hungarian Dance No. 5. Note the rapid increase in tempo for the bursts of six-semiquaver flourishes at beats 7-9, 15-17 and the big ritardando at beats 18 to 24 (the score states poco rit at bar 41 [beat \#18]). Ysaÿe plays the last one and a half beat before in tempo (b. 45 / beat \#26) fast and accelerates all the way to the end of the section. 


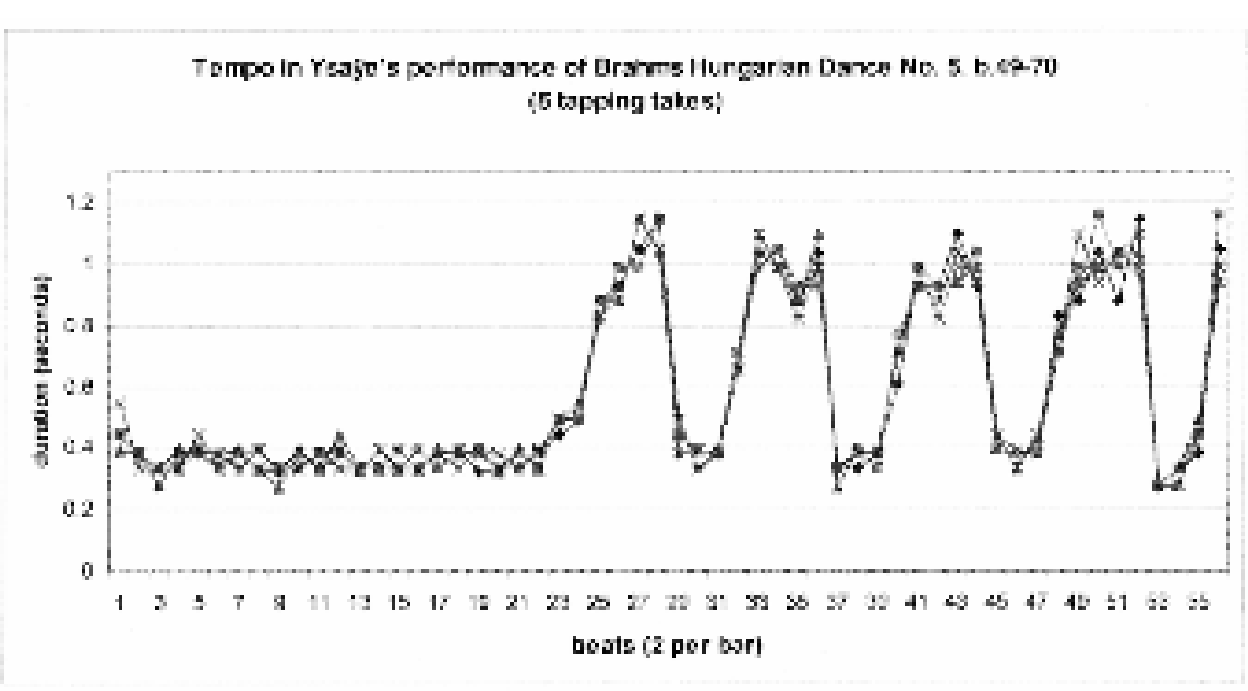

Figure 8: Tempo graph showing Ysaÿe's steady control of tempo in the vivace middle section of Brahms' Hungarian Dance No. 5 (b. 49-70). Here values refer to duration (i.e. the higher the value, the slower the tempo).

There are several lessons that can be drawn from the present investigation and that may deserve further examination. The finding that the difference between Ysaÿe's and his predecessors' use of vibrato may not be so clear cut as modern scholarship posits is important to reiterate. Supporting those who argue for a more gradual change, the present data highlight the role choice of repertoire and approach to projecting the music play in vibrato usage: In romantic musical character and in loud passages their vibrato seems fairly similar, but both Joachim and Sarasate tend to play at a softer volume in general; they project less than Ysaÿe. While he creates expression through a luscious tone, Joachim and Sarasate articulate musical gestures more strongly and in greater detail albeit with a thinner tone, reserving obvious vibrato primarily for additional volume when required.

Another lesson has repercussions for the study of taste and aesthetics as well as performance history. The finding that contemporary opinion could be upheld on several levels (judgment of tempo, tone quality, and musicianship) by reference to aural evidence indicates a degree of stability in human perception and appreciation of music within a broadly based cultural setting across extended historical periods. Current post-modern relativist discourse seems to deny this.

A third lesson relates to the implications of the discovery that the 'severe' and 'classically minded' Joachim who was 'true to the composer's intentions' was criticised for "seldom [doing] anything with an allegro except try to make speed 
do duty for meaning (SHAW, 1981, Vol. 1, p. 933). In other words his interpretations might not only come close to that of the virtuoso Ysaÿe and Sarasate but might also exemplify the 'fast objectivist' performance style that Taruskin (1995) and others describe as 'modernist' and a characteristically twentieth century phenomenon.

Note: This research has been supported by funding from the Australian Research Council (Discovery Project DP0452290).

\section{APPENDIX}

LIST OF WORKS RECORDED BY JOACHIM, SARASATE AND YSAŸE REISSUED ON OPAL CD 9851

Joseph Joachim (1903):

Bach: Partita in B minor: Bourrée

Bach: Sonata in G minor: Adagio

Joachim: Romance in $\mathrm{C}$ major

Brahms: Hungarian Dance No. 1 in G minor

Brahms: Hungarian Dance No. 2 in D minor

Pablo Sarasate (1904):

Sarasate: Zigeunerweisen, Op. 20, No. 1

Sarasate: Capricio Vasco

Sarasate: Capricio Jota

Sarasate: Tarantella

Sarasate: Miramar (Zortzico)

Sarasate: Habañera

Sarasate: Zapateado

Chopin: Nocturne in E flat, Op. 9, No. 2

Bach: Partita in E major: Prelude

\section{Eugène Ysaÿe (1912):}

Chabrier: Scherzo-Valse (»Pièce Pittoresques« — 10)

Fauré: Berceuse, Op. 16

Mendelssohn: Finale - Allegro moto (Concerto in E minor, Op. 64)

Wieniawski: Two mazurkas

(a) »Obertass « in G, Op. 19, No. 1

(b) »Dudziaiz« in D, Op. 19, No. 2

Brahms: Hungarian Dance No. 5 in G minor (arr. Joachim) 


\section{LIST OF REFERENCES}

BELLMAN, Jonathan (2003). Performing Brahms in the style Hongrois. Performing Brahms: Early evidence of performance style. Musgrave, M. and Sherman, B. D. (eds). Cambridge: CUP, 327-348.

BOTSTEIN, Leon (1992). Listening through reading: Musical literacy and the concert audience. 19th-Century Music 16/2 (Fall), 129-145.

BOWEN, José A. (1993). The conductor and the score: the relationship between interpreter and text in the generation of Mendelssohn, Berlioz and Wagner. PhD diss., Stanford University. Ann Arbor, Mich.: UMI Dissertation Services.

DAY, Timothy (2001). A century of recorded music: Listening to musical history. New Haven (Conn.): Yale UP.

FABIAN, Dorottya (2005). Towards a performance history of Bach's Sonatas and Partitas for Solo Violin: Preliminary investigations. Essays in Honor of László Somfai: Studies in the Sources and the Interpretation of Music. Vikárius, L. and Lampert, V. (eds). Lanham, Maryland: Scarecrow Press, 77-99.

GRONOW, Pekka and SAUNIO, Ilpo (1998). An international history of the recording industry. (Eng. trans., Moseley, C.). London \& New York: Cassell.

HAUCK, Werner (1975). Vibrato on the violin (Eng. trans., Rokos, K.). London.

KATZ, Mark (1999). The phonograph Effect: The influence of recording on listener, performer, composer, 1900-1940. PhD diss., The University of Michigan.

KATZ, Mark (2000). Aesthetics out of exigency: violin vibrato and the phonograph. Music and technology in the twentieth century. Braun, H-J. (ed.). Baltimore-London: The John Hopkins University Press, 174-185.

KATZ, Mark (2004). Capturing sound: How technology has changed music. Berkeley: University of California Press.

KUHN, Terry L. and BOOTH, Gregory D. (1988). The Effect of melodic activity, tempo change, and audible beat on tempo perception of elementary school students. Journal of Research in Music Education. 36/3 (Fall), 140-55.

MAITLAND, Fuller (1905). Joseph Joachim. London \& New York: The Bodley Head.

MILSOM, David (2003). Theory and practice in late nineteenth-century violin performance: An examination of style in performance 1850-1900. Aldershot: Ashgate.

MOSER, Andreas (1898). Joseph Joachim - Ein Lebensbild. Berlin: B. Behyr's Verlag. 
MUSGRAVE, Michael and SHERMAN, Bernard, D. (eds) (2003). Performing Brahms: Early evidence of performance style. Cambridge: CUP.

PHILIP, Robert (1992). Early recordings and musical style. Cambridge: CUP.

PHILIP, Robert (2004). Performing music in the age of recording. London-New Haven: Yale UP.

SMART, George (1859). A Beethovenian invitation from George Smart to Joseph Joachim for private music making with Joseph Ries in August 1859 in Surrey England. Facsimile. The Beethoven Journal 17/2 (Winter 2002), 74-5.

ROTH, Henry (1990). The Strad century. The Strad 101 (May), 365-75.

SCHOLES, Percy, A. (1947). The mirror of music, 1844-1944: a century of musical life in Britain as reflected in the pages of the Musical Times. London: Novello \& Co.

SHAW, Bernard (1981). Shaw's music: the complete musical criticism in three volumes. (Ed. D. H. Laurence). London: Max Reinhardt, the Bodley Head.

SHELDON, Deborah A. - GREGORY, Diane (1997). Perception of tempo modulation by listeners of different levels of educational experience. Journal of Research in Music Education 45/3 (Fall), 367-79.

TARUSKIN, Richard (1995). Text and act - Essays on music and performance. Oxford-New York: OUP.

TURNER, Richard (2004). Style and tradition in string quartet performance: A study of 32 recordings of Beethoven's op. 131 quartet. PhD dissertation, The University of Sheffield.

WOLFE, Joe (2001). Note names, midi numbers and frequencies. Internet site of the Music Acoustics Lab, School of Physics, The University of New South Wales [accessed 25 October 2005]: http://www.phys.unsw.edu.au/ jw/notes.html

ZEITLIN, Zvi (1990). The emergence of the great violin virtuoso as traced through the history of ornamentation. Strings. March/April, 48-54. 
Sažetak

\section{SNIMKE JOSEPHA JOACHIMA, EUGÈNEA YSAŸEA I PABLA SARASATEA U SVIJETLU NJIHOVE RECEPCIJE KOD BRITANSKIH KRITIČARA 19. STOLJEĆA}

Novinska recepecija znamenitih violinista 19. stoljeća kao što su bili Joseph Joachim (1831-1907), Pablo Sarasate (1844-1908) and Eugène Ysaÿe (1858-1931) važan je izvor za povijesno proučavanje izvodilaštva. Uspoređivanje više izvještaja tijekom godina sa sačuvanim zvučnim zabilježbama donosi uvid u to što su te snimke mogle uhvatiti od umjetnosti ovih svirača.

Kritike također informiraju o očekivanjima, koncertnim praksama i ukusu u 19. stoljeću. Razabiremo da su sve do duboko u 19. stoljeće kritike izbjegavale komentirati izvođenje i raspravljale samo o skladbama. Međutim, s postupnim ustanovljenjem standardnog repertoara interpretacije djelâ postajale su od 1850-ih nadalje važno žarište kritike, sadržavajući neke komparativne komentare. Tako nedavno uočene spoznaje o razlikama između spomenutih violinista zadobivaju nove perspektive. Na primjer, Joachim se potvrđuje kao 'autoritativni' interpret klasičnih djelâ, osobito Bacha. No, uspostavlja se da je, barem što se Bernarda Shawa tiče, "Ysaÿeiva snaga polifonijskog sviranja omogućila mu da se suprotstavi svakoj usporedbi«. S druge pak strane, Ysaÿe virtuoz je, a ne 'cijenjeni' i 'strogi' Joachim, bio onaj za kojeg je dokazano da je točnije slijedio partituru, barem u Brahmsovim Mađarskim plesovima.

I komentari suvremenika i dokazi sa snimki upućuju na to da su Joachim i Sarasate svirali s mekanijim i manje izraženim tonom nego Ysaÿe, čiji je tembar opisan kao 'sočan'. Čini se da je vibrato bio više dijelom proizvodnje tona u Ysaÿevu sviranju, dok su ga Joachim i Sarasate upotrebljavali u različitim stupnjevima i s različitim učincima, najčešće kako bi dodali volumen i intenzitet nekim pasažama. Međutim, važno je istaknuti da se Joachimov vibrato češće čuje u romantičkom repertoaru nego kada svira Bacha.

Postojala je tendencija da se brzi stavci sviraju vrlo brzo. To zapažaju na jednako negativan način i njihovi suvremenici. Ova pojava upućuje na stupanj stabilnosti u ljudskoj percepciji i glazbenom ukusu tijekom duljih vremenskih razdoblja, što je značajno otkriće s implikacijama za postmoderne relativističke teorije. 
